\title{
Adaptation of Mobile Learning in Higher Educational Institutions of Saudi Arabia
}

\author{
Fathima Sakeena Narayanasamy \\ College of Computer Science \& Information \\ Systems, Jazan University, Jazan \\ Kingdom of Saudi Arabia
}

\author{
Jarina Begum Khan Mohamed \\ College of Computer Science \& Information \\ Systems, Jazan University, Jazan \\ Kingdom of Saudi Arabia
}

\begin{abstract}
Mobile learning (m-learning) is a new learning approach, relatively new research concept, has become an emerging learning trend for education system with mobile devices, internet and wireless technologies. M-learning is the next generation of E-learning, which will provide easy access and wide availability to students with more collaborative learning opportunities and activities. This study aims to investigate the students' awareness of m-learning and its aspects, the adaptation of m-learning in education and the disclosure of $\mathrm{m}$ learning services. Data was collected through the questionnaire, 300 under graduate students from various departments of Jazan University were participated successfully in this research. The results indicated that students have an adequate knowledge and awareness in $\mathrm{m}$ learning and provided the strong evidence on readiness of students to accept mobile technologies for their learning process. This result also showed an indication of students' expectations towards university services via mobile phones in higher educational institutions.
\end{abstract}

\section{General Terms}

Mobile learning, Jazan University

\section{Keywords}

Mobile learning, educational services

\section{INTRODUCTION}

Mobile learning is a technique that uses handheld devices, together with wireless and mobile phone networks, to facilitate, support, enhance and extend the reach of teaching and learning [1]. M-learning is expected to be delivery of electronic learning material on mobile computing devices and offer the advantages of learning anywhere and anytime with mobile devices [6]. M-learning as one of the up-and-coming educational and training method seems to be fastest developing in educational market. M-learning enables students to merge their learning experiences in a shared collaborative environment [2]. To adopt and utilize this $\mathrm{m}-$ learning technology in higher educational institutes must need to understand the students' awareness of m-learning and its impacts with expected services. The main reason for choosing mobile learning in our research is its popularity especially with young students today. Almost every person in Jazan University owns at least one mobile phone. The cost of mobile devices and calling rates are quite affordable and the mobile infrastructure in Saudi Arabia is well established resulting in most people acquiring mobile devices with improved features every year.

\section{BACKGROUND}

Generally, Mobile learning has been defined as learning that takes place via wireless devices such as mobile phones, personal digital assistants (PDAs), or laptop computers [2]. Elliott Masie defines mobile learning quite broadly as, "Mobile learning is defined as all 'knowledge in the hand.' It includes the use of mobile / handheld devices to perform any of the following: Deliver education / learning, Foster communications / collaboration, Conduct assessments / evaluations, Provide Access to performance support / knowledge". John Traxler [7] defines mobile learning as, "Mobile learning can perhaps be defined as any educational provision where the sole or dominant technologies are handheld or palmtop devices." A definition of mobile learning [8] should therefore be widened to include, any sort of learning that happens when the learner is not at a fixed, predetermined location, or learning that happens when the learner takes advantage of the learning opportunities offered by mobile technologies. M-learning is an emerging form of elearning that offers the opportunity for both teachers and students to interact with educational material and services using mobile devices, independent of time and space. Availability and innovations of mobile technology such as wireless infrastructure, high bandwidth and mobile devices moved e-learning to m-learning era [6].

\subsection{Technologies of m-learning}

Mobile learning utilizes various technologies such include mobile devices, mobile software applications, mobile operating systems, transport of data and delivery options for contents. Figure 1 shows the technologies clearly.

\begin{tabular}{|c|c|c|c|c|}
\hline \multicolumn{5}{|c|}{ Mobile Technologies } \\
\hline $\begin{array}{l}\text { Transport } \\
\text { options } \\
\text { - GPRS } \\
\text { - GSM } \\
\text { - Blue- } \\
\text { tooth } \\
\text { - } 3 \mathrm{G} \\
\cdot 4 \mathrm{G}\end{array}$ & $\begin{array}{l}\text { Devices } \\
\text { options } \\
\text { - Mobile } \\
\text { phones } \\
\text { - Smart } \\
\text { phones } \\
\text {-PDA } \\
\text {-Palm } \\
\text { computers }\end{array}$ & $\begin{array}{l}\text { Delivery } \\
\text { options } \\
\text { - SMS } \\
\text { - MMS } \\
\text {-E-mail } \\
\text { - WAP } \\
\text { - HTTP }\end{array}$ & $\begin{array}{l}\frac{\text { Software }}{\text { options }} \\
\text {-J2ME } \\
\text { - API } \\
\text {-MIDP } \\
\text {-XML } \\
\text { - ASP.NET }\end{array}$ & $\begin{array}{l}\frac{\text { Operating }}{\text { system }} \\
\text { options } \\
\text { - Symbian } \\
\text { OS } \\
\text { - Mobile } \\
\text { Windows } \\
\text { - Palm OS } \\
\text { - iPhone OS } \\
\text { - Android }\end{array}$ \\
\hline
\end{tabular}

Fig 1: Mobile Technologies

\subsubsection{Mobile transport options}

The Advances in computer technology, intelligent user interfaces, context modeling applications and recent developments in the field of wireless communications, including $\mathrm{Wi}-\mathrm{Fi}$, Bluetooth, multi-hop wireless LAN and the 
global wireless technologies such as GPS, GSM, GPRS, 3G, $4 \mathrm{G}$ and satellite systems have created a wide array of new possibilities for technology users [3].

\subsubsection{Mobile Devices options}

There are several devices that support mobile learning camera phones, smart phones, and personal audio players the most popular being PDAs, which are wallet-sized computers designed as a combination of digital calendars and address books. These are also generically known as Palm computers [8].

\subsubsection{Mobile data delivery options}

Mobile technologies potentially promote, facilitate, and enhance student collaboration and interaction, processes that serve as a means for accessing, discovering, discussing, and sharing environmental concerns via multimedia messaging services (MMS), short messaging services (SMS), electronic mail, or messengers [4]. Students can converse with each other, question each other, and share opinions about environmental concerns. Collaboration could also occur outside the classroom, unlimited by geography, space, or time, although traditional classroom instruction infrequently supports collaboration [5].

\subsubsection{Mobile Software}

Sun Microsystems designed the Java 2 Micro Edition (J2ME), an Application Programming Interface (API) to develop software for small and resource constrained devices. The key element of J2ME is Mobile Information Device Profile (MIDP) which provides a standard Java runtime environment for popular mobile information devices, such as cell phones and PDAs. MIDP is a widely adopted platform of choice for mobile applications, deployed on millions of cell phones and PDAs globally, and is also supported by leading integrated development environments (IDEs). Microsoft Visual Studio 2008 and ASP.NET 3.5 include support for working with XML and creating mobile Web applications [9].

\subsubsection{Mobile operating systems}

There are many players in the area of mobile device operating systems (OS) such as Symbian OS, Microsoft Windows for Mobile, Palm OS, Mac OS X, Linux, iPhone OS and Android. Many operating system providers have also developed SDK platform compliant to their operating system [10].

\subsection{Advantages}

M-learning through a mobile device makes learning truly personalized. The learners have the option to choose learning content based on their interest, thus making learning very learner-centric [4]. The flexibility to access immediate jobspecific information using mobile devices helps to increase the productivity of an individual. The advantages of $\mathrm{m}$ learning are listed as follows - content consistency, collaborative learning, personalized learning, , learner centric, increased productivity, on demand content, continuous learning support, multimedia content delivery, enhance interaction, simple , intuitive, low physical and technical efforts [8].

\subsection{Limitations}

M-learning presents unique challenges like slow download speed and limited internet access, small screen sizes with poor resolution, color and contrast awkward text input, limited memory, small screen size of mobile device, limited computational capabilities, limited battery life and need more time to find information [4].

\subsection{Applications}

The number of Mobile Learning content applications has exploded over the last two years. The applications are grouped as follows [10], language learning, travel and tourism, academic test preparation, general education, study guides, and reference, how-to manuals and guides, simulation and game-based learning , location-based learning , medical, health, nutrition, and fitness, business, sales, and finance , handheld decision support and performance support, professional licensure, continuing education , continuing medical education, professional training and development. Even in the presence of an education category in a store, Mobile Learning apps are spread out among several categories including games, travel, reference, medical, and health. For example, a large percentage of learning apps designed for children are game-based and often tagged as games instead of education [4].

\subsection{Services}

While m-learning is growing rapidly in the higher education environments, the focus is still on two types, learning material services and administrative services. M-learning services have two main types. Pedagogical services such as learning materials and Informative services such as admission and registration [3].

\section{METHODOLOGY}

In this study the questionnaire was used as a main instrument for data collection. 300 questionnaires were distributed to students of various departments of academic campus for girls, Jazan. The study and its importance were briefly explained. The questionnaire contains 8 sections.
$\checkmark$ Section 1: Student's profile
$\checkmark$ Section 2: Awareness on mobile devices
$\checkmark$ Section 3: Awareness on mobile technologies
$\checkmark$ Section 4: Usage of mobile applications
$\checkmark$ Section 5: Knowledge on mobile limitations
$\checkmark$ Section 6: Knowledge on mobile advantages
$\checkmark$ Section 7: Expected mobile services
$\checkmark \quad$ Section 8: Expectations on m-learning

\section{DATA ANALYSIS \& RESULTS}

The analysis and survey results are presented based on these 300 valid respondents.

\subsection{Student's profile}

Table 1. Student's profile

\begin{tabular}{|c|c|c|c|}
\hline Profile & Classification & No & Percentage \\
\hline \multirow{3}{*}{ Department } & CS \& IS & 110 & $37 \%$ \\
\cline { 2 - 4 } & Arch & 70 & $23 \%$ \\
\cline { 2 - 4 } & Business & 120 & $40 \%$ \\
\hline \multirow{4}{*}{$\begin{array}{c}\text { Level of } \\
\text { studying }\end{array}$} & Level 1 & 80 & $27 \%$ \\
\cline { 2 - 4 } & Level 2 & 50 & $17 \%$ \\
\cline { 2 - 4 } & Level 3 & 90 & $30 \%$ \\
\cline { 2 - 4 } & Level 4 & 50 & $17 \%$ \\
\hline \multirow{3}{*}{ Age } & Level 5 & 30 & $10 \%$ \\
\cline { 2 - 4 } & $<=18$ & 10 & $3 \%$ \\
\cline { 2 - 4 } & $19-21$ & 250 & $83 \%$ \\
\cline { 2 - 4 } & $22-24$ & 40 & $13 \%$ \\
\hline
\end{tabular}

As shown in Table 1,37\% of participants from Department of Computer Science, 23\% from Department of Architecture, $40 \%$ from Department of Business administration. Out of 300 participants, $27 \%$ from level 1, $17 \%$ from level 2, 30\% from 
level 3,17\% from level 4 and 10\% from level 5. 83\% of participants are in the age between $19-21$.

\subsection{Awareness on mobile devices}

As shown in Figure 2, all the students have the experience to use mobile phones. $80 \%$ of participants own smart phones, $73.3 \%$ of participants own basic mobile phones. PDA and Tablet PC have owned by $30 \%$ of students. This result shows that students have adequate awareness on mobile devices, which used in m-learning environment.

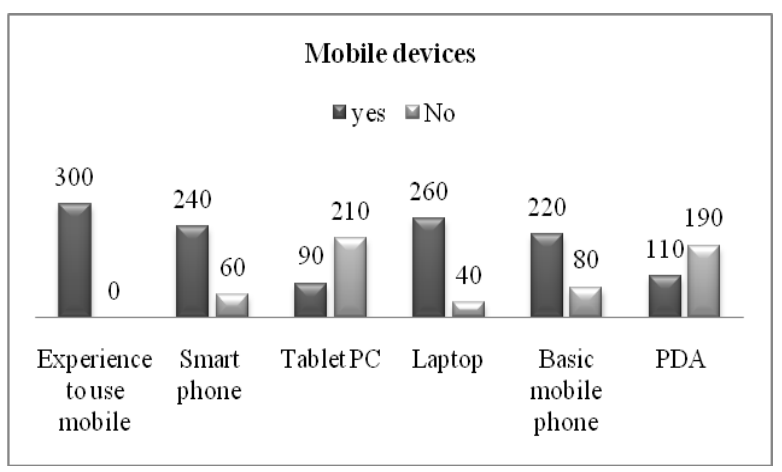

Fig 2: Awareness on mobile devices

\subsection{Awareness on mobile technologies}

As shown in Figure 3, 90\% of participants using Wi-Fi, 97\% of them using internet in mobile, $97 \%$ of them using blue tooth, $53 \%$ of participants using GPRS, $63 \%$ of them using WAP and $40 \%$ of them using 3G. This result shows that students have quite awareness on mobile technologies, which used in m-learning environment.

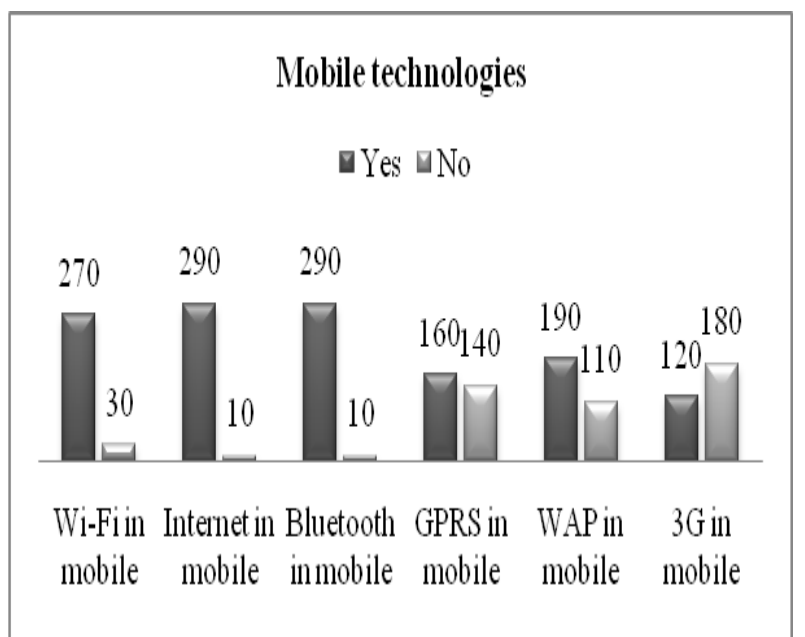

Fig 3: Awareness on mobile technologies

\subsection{Usage of mobile applications}

As shown in Table 2, almost all the applications are used by participants. SMS has been used extremely, $66.67 \%$ of participants used it. Online services used frequently by $63.33 \%$ of participants. Video calling, Sending emails, Word Processing, Dictionary, Notes, Calendar, Social networks are not used by participants more than $20 \%$. This result shows that the students use almost all the above listed application. Students have fair knowledge to use the mobile applications.

\subsection{Knowledge on mobile limitations}

As shown in Table 3, slow data connection (83.33\%) and unsecure internet connection $(80 \%)$ are the highest ranked limitations. The other limitations also concerned by participants very closely percentages.
Table 2. Usage of mobile applications

\begin{tabular}{|c|c|c|c|c|}
\hline $\begin{array}{c}\text { Mobile } \\
\text { application }\end{array}$ & $\begin{array}{c}\text { Not } \\
\text { used }\end{array}$ & $\begin{array}{c}\text { Rarely } \\
\text { used }\end{array}$ & $\begin{array}{c}\text { Frequen } \\
\text { tly used }\end{array}$ & $\begin{array}{c}\text { Extreme } \\
\text { ly used }\end{array}$ \\
\hline SMS & $3.33 \%$ & $16.67 \%$ & $13.33 \%$ & $66.67 \%$ \\
\hline MMS & $6.67 \%$ & $40.00 \%$ & $30.00 \%$ & $23.33 \%$ \\
\hline Games & $6.67 \%$ & $53.33 \%$ & $36.67 \%$ & $3.33 \%$ \\
\hline Calendar & $20.00 \%$ & $40.00 \%$ & $30.00 \%$ & $10.00 \%$ \\
\hline $\begin{array}{c}\text { Word } \\
\text { processing }\end{array}$ & $23.33 \%$ & $40.00 \%$ & $26.67 \%$ & $10.00 \%$ \\
\hline Chat & $13.33 \%$ & $26.67 \%$ & $36.67 \%$ & $23.33 \%$ \\
\hline $\begin{array}{c}\text { Sending } \\
\text { emails }\end{array}$ & $33.33 \%$ & $20.00 \%$ & $33.33 \%$ & $13.33 \%$ \\
\hline $\begin{array}{c}\text { Online } \\
\text { services }\end{array}$ & $13.33 \%$ & $3.33 \%$ & $63.33 \%$ & $16.67 \%$ \\
\hline $\begin{array}{c}\text { Video } \\
\text { calling }\end{array}$ & $50.00 \%$ & $30.00 \%$ & $13.33 \%$ & $6.67 \%$ \\
\hline $\begin{array}{c}\text { Social } \\
\text { networks }\end{array}$ & $20.00 \%$ & $33.33 \%$ & $33.33 \%$ & $13.33 \%$ \\
\hline Dictionary & $23.33 \%$ & $40.00 \%$ & $26.67 \%$ & $10.00 \%$ \\
\hline Calculator & $0.00 \%$ & $40.00 \%$ & $23.33 \%$ & $36.67 \%$ \\
\hline Notes & $20.00 \%$ & $40.00 \%$ & $40.00 \%$ & $0.00 \%$ \\
\hline
\end{tabular}

Table 3. Knowledge on mobile limitations

\begin{tabular}{|c|c|c|c|}
\hline Mobile limitations & Affect & Not affect & No idea \\
\hline $\begin{array}{c}\text { Need training to use } \\
\text { mobile phone }\end{array}$ & $36.67 \%$ & $36.67 \%$ & $23.33 \%$ \\
\hline $\begin{array}{c}\text { Need training to use } \\
\text { mobile applications }\end{array}$ & $56.67 \%$ & $23.33 \%$ & $16.67 \%$ \\
\hline $\begin{array}{c}\text { Unsecure internet } \\
\text { connection }\end{array}$ & $80.00 \%$ & $13.33 \%$ & $6.67 \%$ \\
\hline Small screen size & $76.67 \%$ & $13.33 \%$ & $10.00 \%$ \\
\hline Small Keypad & $53.33 \%$ & $33.33 \%$ & $13.33 \%$ \\
\hline Limited memory & $63.33 \%$ & $30.00 \%$ & $6.67 \%$ \\
\hline Limited battery & $73.33 \%$ & $20.00 \%$ & $6.67 \%$ \\
\hline $\begin{array}{c}\text { Slow data } \\
\text { connection }\end{array}$ & $83.33 \%$ & $3.33 \%$ & $13.33 \%$ \\
\hline $\begin{array}{c}\text { Need more time to } \\
\text { find information }\end{array}$ & $53.33 \%$ & $26.67 \%$ & $20.00 \%$ \\
\hline
\end{tabular}

\subsection{Knowledge on mobile advantages}

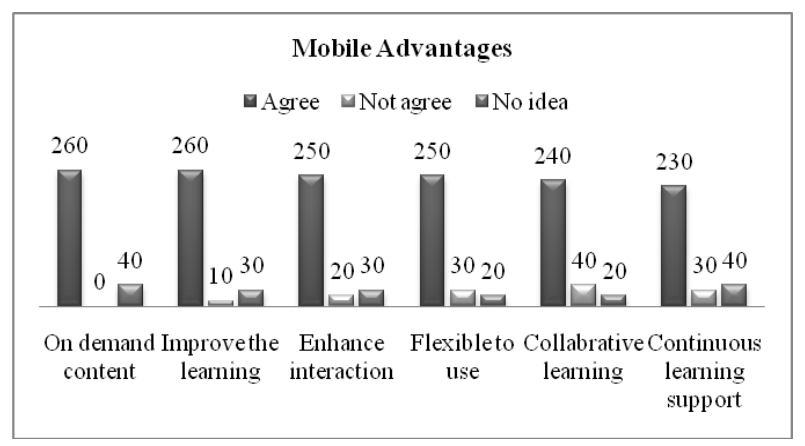

Fig 4: Knowledge on mobile advantages

As shown in Figure 4, participants have fair knowledge about all mobile advantages. In which on demand content $(86.67 \%)$ and improve the learning $(86.67 \%)$ are highly ranked advantages. Enhance interaction $(83.33 \%)$ and flexible to use $(83.33 \%)$ ranked in next place. Collaborative learning $(80 \%)$ and continuous learning support $(76.67 \%)$ ranked at last. This 
result shows students have very good knowledge about mobile advantages.

\subsection{Expected mobile services}

As shown in Table 4, feedback to teachers (93\%) is highly ranked expected service. Course schedule (87\%) and exam results $(87 \%)$ are ranked next. Alerts \& warnings $(80 \%)$ got ranked in third position. All the mobile service expected by above $50 \%$ of students. This result shows that students are interested to get the university services via mobile.

Table 4. Expected mobile services

\begin{tabular}{|c|c|c|c|}
\hline Classification & Interested & $\begin{array}{c}\text { Not } \\
\text { interested }\end{array}$ & No idea \\
\hline $\begin{array}{c}\text { Course } \\
\text { registration }\end{array}$ & $63 \%$ & $30 \%$ & $7 \%$ \\
\hline Time table & $73 \%$ & $20 \%$ & $7 \%$ \\
\hline $\begin{array}{c}\text { Academic } \\
\text { calendar }\end{array}$ & $53 \%$ & $23 \%$ & $23 \%$ \\
\hline $\begin{array}{c}\text { Course weekly } \\
\text { schedule }\end{array}$ & $87 \%$ & $10 \%$ & $3 \%$ \\
\hline $\begin{array}{c}\text { Alerts \& } \\
\text { Warnings }\end{array}$ & $80 \%$ & $17 \%$ & $3 \%$ \\
\hline $\begin{array}{c}\text { Video lectures } \\
\text { MP3 audio } \\
\text { lectures }\end{array}$ & $63 \%$ & $27 \%$ & $10 \%$ \\
\hline $\begin{array}{c}\text { Soft copy of } \\
\text { study materials }\end{array}$ & $60 \%$ & $17 \%$ & $23 \%$ \\
\hline $\begin{array}{c}\text { Exam time } \\
\text { table }\end{array}$ & $70 \%$ & $27 \%$ & $3 \%$ \\
\hline $\begin{array}{c}\text { Exam results } \\
\text { Feedback to } \\
\text { teachers }\end{array}$ & $87 \%$ & $7 \%$ & $6 \%$ \\
\hline
\end{tabular}

\subsection{Expectations on m-learning}

As shown in Figure 5, 77\% of participants expected secure network connection, $73 \%$ of participants expected high speed data connection and efficient support system. 70\% participants expected special trainings for m-learning. $67 \%$ of participants are expected special Wi-Fi zone for implementing m-learning. This result shows that almost $72 \%$ of students expected m-learning in their educational environment.

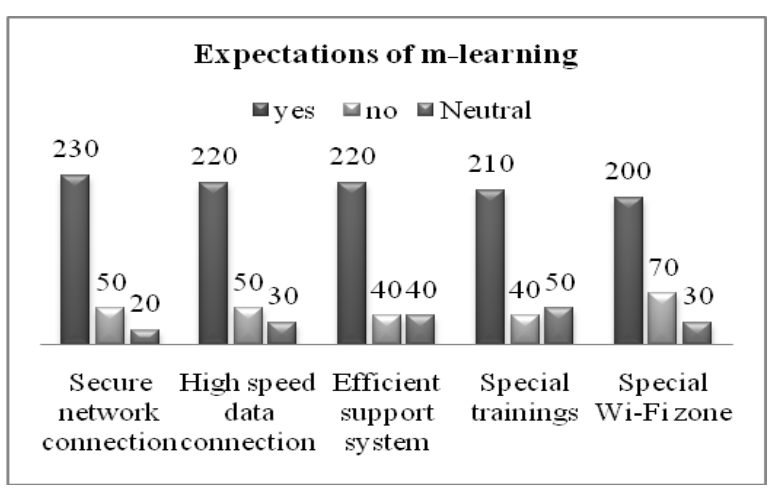

Fig 5: Expectations on m-learning

\section{CONCLUSION}

Nowadays, m-learning is a rising learning trend and a new vital platform for the higher education environments. This study is investigated students' awareness of m-learning and its aspects and adaptation of m-learning based on Jazan University. The findings represented opinions of different levels of students from academic campus for girls, Jazan. The results indicated that Jazan University had the required infrastructure to utilizing m-learning services. Furthermore the results showed that the students had ample knowledge and awareness to use such technology in their learning process. It was also demonstrated that students were quite aware of mobile technologies which used widely in m-learning environment. The results indicated that the students' perceptions of various limitations. The study also found that the most beneficial aspects and advantages of using mobile technologies for learning services were to give students an immediate access to information regardless of place. Students highly ranked several informative m-learning services. This study indeed provides unambiguous evidence on the readiness of students to accept and use m-learning in their educational environment. This may give a hand in supporting and utilizing $\mathrm{m}$-learning services in Jazan University. This study is part of research to investigate adoption and diffusion of m-learning services among students in the higher educational Institutions. This study shows only the students' adaptation, the required infrastructure and architecture to implement $\mathrm{m}$ - learning will be discussed further.

\section{ACKNOWLEDGMENTS}

We thank our college dean Dr. Omar Al-Mushayt, and vicedean Dr. Saleh Al-Turki for their continuous support and encouragement and extend our thanks to all our family members.

\section{REFERENCES}

[1] Kalloo. V,and Mohan. P, "Correlating questionnaire data with actual data in a mobile learning study for high school mathematics", The electronic journal of elearning, Volume 10, Issue 1, (2012), pp76 -89.

[2] Naji Shukri Alzaza, Abdul Razak Yaakub, "Students's mobile information prototype for higher education environment", American journal of economics and business administration, 3(1), (2011), pp81-86

[3] Mohamed Sarab, Laila Elgamal, Hamza Aldabbas, "Mobile learning and Educational environments", International journal of distributed and parallel systems, Volume 3, No 4, July (2012)

[4] Tanya Elias,"Universal Institutional design principles for mobile learning", International review of research in open and distance learning, volume 12, 2, Feb (2011)

[5] Huseyin Uzunbaylu, Nadarie Cavus, Enric Encag, "Using mobile learning to increase the environmental awareness", Computer \&Education, (2009), pp 381-389

[6] Firouz Anaraki, "Assessment of m-learning -A case study: Assumption University of Thailand", Fourth international conference on Elearning for knowledge based society, Nov 18 -19, (2007), Bangkok, Thailand

[7] John Traxler, "Defining mobile learning", IADIS International conference on mobile learning, (2005)

[8] Guidelines for learning in mobile environment, MOBIlearn, June (2003)

[9] Maduri Kumari, Vikram Singh, "Mobile Learning: an emerging learning trend", Tata Consultancy Services, India.

[10] Ambient insight comprehensive report: The US Market for mobile learning products and series: 2010 -2015 Forecast $\&$ analysis. 


\section{AUTHOR'S PROFILE}

\section{Fathima Sakeena Narayanasamy}

Fathima Sakeena was born in India, on February 24, 1981. She obtained her B.E degree in Electronics \& Communication Engineering from Bharathidasan University, Tiruchirappalli, India on 2002. She received her M.Tech degree in Information Technology from Anna University, Chennai, India on 2005. Her research interests include mobile computing; cloud computing, E-learning, M-learning, and Biometrics and information security. Currently, she is a lecturer in College of computer science \& Information systems at Jazan University, Saudi Arabia.

\section{Jarina Begum Khan Mohamed}

Jarina Begum was born in India, on December 8, 1974. She obtained her BSc degree in Computer science from Madurai Kamaraj University, India on 1992. She received her MCA degree in Computer Applications from Madurai Kamaraj University, India on 1998. She pursued her M.Phil degree from Madurai Kamaraj University, India on 2008. Her research interests include Biometrics, Information security, cloud computing, E-learning and M-learning. Currently, she is a lecturer in College of computer science \& Information systems at Jazan University, Saudi Arabia. 